\title{
MODERN FEATURES OF ADMINISTRATIVE AND LEGAL REGULATION OF INNOVATION ACTIVITIES OF ENTERPRISES IN TERMS OF ECONOMIC COMPETITION
}

\author{
Serhii Nenko', Kateryna Holovko², Oleksandr Dzera ${ }^{3}$
}

\begin{abstract}
The subject of the study are organizational and economic relations arising in the process of administrative and legal support of innovation activities of enterprises in terms of economic competition. Methodology. Instrumental and methodological apparatus of the study consists of the applied methods of economic analysis of organizations, statistical methods, sample observation, method of economic modeling, grouping, generalization, expert evaluations, methods of economic theory, marketing, etc. The aim of the article is to study modern features of administrative and legal regulation of innovative activity of enterprises in conditions of economic competition. The results of the study are to identify the typical principles of state innovation policy. The study of existing principles shows that they are largely based on administrative and legal methods of regulation, which is explained by the organizational and managerial focus of the principles of state innovation policy. Finally, the conclusion about the need to unify the principles of state innovation policy in relation to enterprises operating in a competitive environment is formulated. Conclusion. Analysis of the regulatory framework governing the innovative activities of enterprises has revealed a number of problems. The most important of them are: absence of unity in determining the fundamental concepts of the innovation sphere; lack of unity in determining the powers of executive authorities in the innovation sphere; inconsistency in the construction of executive authorities that regulate innovation activity; non-unity in determining the powers of the executive bodies of state power; legal and linguistic uncertainty in the formulation of the powers of the executive authorities; ambiguity of the range of issues on the adoption of normative legal acts regulating relations in the field of innovation; absence of unity in the definition of the object of state support; no uniformity in the interpretation of the concept of "state innovation policy" in the laws; vagueness and ambiguity in the definition of goals and objectives of state innovation policy; different interpretations of the concept of "state support to subjects of innovation activity"; unreasonable limitation of the range of recipients of state support; presence of excessive administrative barriers in obtaining state support. Based on the above, it can be concluded that the administrative-legal regulation in the field of innovation activities of enterprises in a competitive environment is in its formative stage and needs further improvement.
\end{abstract}

Key words: enterprises, innovation, innovative activity, administrative support, legal support, economic structures, competitiveness, administrative law.

JEL Classification: E69, F15, F20, K22, K23

\section{Introduction}

The legal regulation of innovative activity is considered from the point of view of administration by various state bodies and officials.

Now all over the world there is an understanding that in the future profits can only be obtained by defeating the competitor (Gilbert, 2006). But this can be done not by expanding production, but by inten- sifying it on the basis of new technologies, new organizational solutions.

Knowledge of peculiarities of legal regulation of innovative activity will help in the future, when taking the appropriate position in the bodies of power and management, as well as when engaging in entrepreneurship. It should be remembered that the legal regulation of innovative activity is an

\footnotetext{
Corresponding author:

${ }^{1}$ International University of Business and Law, Ukraine.

E-mail: nenkofamily@ukr.net

ORCID: https://orcid.org/0000-0003-2473-2823

${ }^{2}$ Black Sea Research Institute of Economy and Innovation, Ukraine.

E-mail: k.v.mozharovska@gmail.com

${ }^{3}$ Kyiv Regional Center of the National Academy of Legal Sciences of Ukraine, Ukraine.

E-mail: dzerao@gmail.com
} 
interdisciplinary course that combines both civil and administrative factors. The study begins with administrative factors, which determine many of the concepts and phenomena that exist in civil law.

Most economists consider the innovative activity of enterprises as a continuous innovative process of scientific, technical, technological and organizational changes (Tkacheva, Osadchuk, Kapustina, Kobersy, 2020). The period of creation, distribution and use of innovations is called the innovation cycle. Despite the differences in the understanding of the term "innovation", all researchers agree that innovation is of great importance for the development of a country's economy. At the same time, under the conditions of innovative economy (knowledge economy, noospheric economy) the approach to the sources and resources of economic growth changes radically. The principle of rational use of material, labor and financial resources becomes decisive. Such socio-economic institutions as science, education and management begin to play a leading role. Qualitative changes in the economy can be achieved only by improving the legal regulation of relations in the sphere of science and education management. The first steps in this direction in Ukraine have already been taken, but much remains to be done in terms of improving the legal support for the development of innovative businesses, especially in a competitive environment.

Today, manufacturers of goods have entered into a fierce struggle for the consumer - the competition in the market has increased significantly. As experience shows, more often than not, the one who pays attention to innovation wins. Nothing gets a manager more focused on innovative ideas than the realization that manufactured goods may lose relevance in the near future. Innovation is fundamental to the success of any enterprise, because every time the need to interest the consumer increases. In addition, most domestic enterprises have long been in need of modernization.

\section{The essence of integrated economic structures in the modern world, their forms, types and structure}

The country's transition to the course of import substitution, ensuring the dynamics of economic growth in conditions of economic instability revealed the need for practice-oriented convergence of science and production, the search for new directions of effective development of business structures, the introduction of progressive ways to organize their activities and increase the rate of production of innovative products. One of the ways to enhance national innovation processes is to optimize approaches to the use of different types of resources by economic agents. Thus, under equal economic conditions, it is the possession of significant reserves of resources and their rational consumption not only provides additional competitive advantages to the commercial structure and enhances its entrepreneurial activity, but also affects the specifics of innovation and features of the formation of the innovative potential of the enterprise. In this regard, modern conceptual understanding of the essence of innovation and innovation capacity of the organization, as well as the use of effective mechanisms for their management, predetermine the ability of the economic entity to develop fundamentally new products, strengthen its competitiveness and adequately respond to current market changes (Arrow, 1962).

For a more in-depth study of the innovation potential of the organization and its structure, first of all, it is necessary to define the concept of "innovation", since at present in the scientific literature there is no one frame of mind, which would clearly reveal the relationship between the categories of "innovation" and "innovation potential" (Caiazza, 2015).

Comparison of scientific definitions allows to draw a conclusion about the synonymity of the concepts of "novelty", "innovation" and "novation" in terms of similar essence of economic phenomena they denote (qualitatively new additions or changes, affecting the final actions or results) (Baregheh, Rowley, Sambrook, 2009).

Given the above, it seems possible to define innovation as a complex process of formation of an advanced idea and technology development, implementation of innovative ways of organizing production and management, as well as realization of qualitatively new products or services, due to different conditions of macro- and micro environment of economic entity functioning. At the same time, the main components (theoretical concept, technical invention, commercial use) and properties (scientific and technical novelty; practical applicability; commercial feasibility) are considered to be well enough structured.

Revealing the relationship of the properties and components of innovation, it can be noted that the theoretical concept of a new idea as a starting point or the beginning of innovation must necessarily have scientific and technological novelty (Gerbing, Anderson, 1988). Further development of the theoretical concept of innovation and its transformation into a real product (process) is formalized as an invention, as a result of which a new, practically applicable object appears at the junction of science and technology. The transition of an invention into the category of innovation directly occurs through its use in economic activity for the purpose of profit, since innovation itself is ultimately a direct way of commercializing conceptual ideas into real economic practice (OECD, 1996). Thus, the objective goal of creating innovation should be to ensure the competitiveness of an economic entity that knows how to aggregate advanced knowledge and service 
research projects, promptly regulating its economic processes and effectively accumulating the power of its innovation potential (Dasgupta, Stiglitz, 1980).

It should be noted that in the study of the innovative potential of the enterprise it is important not only to understand the essence and components of innovation, but also to consider the basis on which various types of innovations in the economy are distinguished.

Analysis shows that as the main classification attributes of innovation is most appropriate to use the following: the objectives of innovation, the significance of innovation, the scope of innovation, the reasons for their emergence, the nature of the needs to be met, the place of innovation in the production system of the economic entity. Such groupings of innovations and the allocation of their individual types can more fully justify the essence of the innovative potential of the enterprise and determine the main directions of its formation and development. However, the interpretation of the innovation potential of the organization is impossible without a separate definition of the concept of "potential" (Hasan, Tucci, 2010).

The term potential (from the Latin word potential - power) is polysemous and is widely used in natural science and humanities literature to denote various categories in physics, chemistry, mathematics, metallurgy, ecology, linguistics, and biology (Baregheh, Rowley, Sambrook, 2009).

In the broadest sense of the word, potential is the totality of all available capabilities, means in any field, sphere. In the applied sense, potential is an "opportunity" or "capability," but at any given time it can denote the totality of the means that predetermine that capability. In a figurative sense, potential is understood as a degree of power in some respect (Fellner, 1951).

In general, it can be concluded that interpretations of potential are varied and the specifics of their presentation depend on the particular field or area of knowledge within which the term is considered.

In modern economic conditions it is customary to allocate a variety of types of potential of commercial structures, among which the key importance, at the junction of a number of other potentials of socioeconomic systems, belongs to the innovation potential as an important condition for ensuring competitiveness and economic efficiency of their functioning (Androshhuk, Davymuka, 2015).

Based on the above materials of the study of the essence of the terms "innovation" and "potential" and given the particular importance and number of structural links of the place of innovation potential in relation to other types of potentials of socio-economic systems, it is necessary to dwell on the content of the concept of "innovation potential of the enterprise" (Caiazza, 2015).
The work considers it necessary to clarify the formulation of the essence of innovation potential of the modern economic entity, combining the key aspects of the resource and productive approaches. The innovation potential of an enterprise should be understood as a rationally organized set of its resources and key competencies, determining the dynamic ability to carry out qualitatively new transformations and ensure the effectiveness of the results of innovation activities in accordance with the needs of the changing environment. In turn, the intensity of activity on the development and introduction of new or improved products into the economic turnover of the enterprise is an innovative activity.

Thus, the formation and use of innovative potential by the enterprise should be based on the rational use and reconfiguration of its resources, processes and relationships, taking into account the needs of the turbulent market, contributing to the growth of competitiveness of the economic entity, increasing its innovative activity and innovation efficiency. At the same time, effective management of innovation potential will allow the enterprise not only quickly adapt to the risks and changes in the external environment, but also increase the overall sustainability of the organization in adverse circumstances.

It is obvious that the effectiveness of the processes of formation and use of innovation capacity of a commercial organization depends on a clear understanding of the composition of its elements and their relationships. At the same time, the existing variety of models describing the structure of innovation potential of an economic entity determines the relevance of their analysis, systematization and improvement of the content.

\section{Features of the innovative activity of the enterprise in a competitive environment}

Experience shows that the person who focuses on innovation first wins most often. Nothing makes a manager focus on innovative ideas as much as the realization that manufactured goods may lose relevance in the near future. Innovations are a fundamental factor of successful production activity of any enterprise, because with each time the need to interest the consumer increases. In addition, the majority of domestic enterprises have long been in need of modernization.

The evolutionary trend in economic theory, which is increasingly taking shape in a new paradigm, is based on the idea of economic natural selection. The development of the most competitive economic subjects occurs at the expense of the displacement of other members of the population of economic subjects from the economic space. The process of economic natural selection forms a certain "organizational 
genotype" - the properties and characteristics of economic subjects that allow them to survive and develop in the changing conditions of the economic environment. Routine processes of behavior of economic subjects are considered from the point of view of evolutionary economics as the main subject of research. Their role in economic development can be compared to the role of genes in biological evolution. In the process of innovative competition an important role is played by the procedures of searching for new technical and organizational solutions aimed at increasing the stability in the competitive struggle. Their result is the formation of new routines in interaction with the economic environment, fixed by "natural selection".

The main thesis of our research, corresponding to the institutional-evolutionary direction of economic theory, is the following: innovative competition in its most distinct form is displaced from the sphere of production of goods (services) and even from the sphere of technological preparation of production to the sphere of creation of institutional advantages of technological development of the firm. The product life cycle in the context of innovative competition acquires an additional stage. In addition to the stage of scientific development, which lays down all the competitive characteristics of the subsequent product (service) life cycle, including the conditions for its operational modernization (updating of operating systems and computer programs) and subsequent disposal, is formed by what is proposed to call the stage of institutional and technological design of the product life cycle (Azoev, 2010). At this stage, firms compete to create an institutional innovation environment that will support the entire subsequent life cycle and create a positive image of the company's technological capabilities and prospects. The most acute and fierce forms of competitive rivalry move into areas of control over scarce resources that enable the formation and maintenance of this institutional and innovative environment. This environment allows a company to conquer an increasing number of potential markets with currently uncertain prospects (Blundell, Griffith, Van Reenen, 1999).

For example, the Korean Samsung Group is ready to allocate more than 20 billion dollars for these purposes. One of the most promising areas of investment is green energy and innovative ways to save energy. The company, which makes a wide range of goods, from clothing to high-tech electronic products, has announced that it is ready to commit nearly $\$ 20.6$ billion to research and expansion over the next decade. Five areas are recognized as priority areas for Samsung's development: solar cell production, development of batteries for hybrid and electric cars, improvement of LED technology, biopharmaceuticals, and creation of medical equipment. The main focus will be on the development of products using LEDs. Samsung is allocating the most money for research and expansion in this area $-\$ 7.6$ billion. Much of the investment, $\$ 5.3$ billion and $\$ 4.8$ billion, respectively, will be spent on the development of solar energy and the creation of powerful batteries for cars.

It is noteworthy that Samsung was not the only electronics manufacturer that decided to increase its own spending on research activities. Previously, such competitors as Toshiba and Sanyo made similar statements. The first company has already allocated about 14 billion dollars. For its own development over the next three years. These funds will mainly be used to finance new Toshiba assembly facilities, as well as to improve the equipment of existing factories. The Japanese company Sanyo plans to increase spending on research in the field of solar energy and batteries in three years it intends to spend more than 2 billion dollars on such developments, making serious competition in these areas Samsung (Tsai, 2018).

Competition is increasingly moving into the sphere of potential markets, becoming proactive and thus non-market, or rather, pre-market, if one understands the market as an established system of institutions serving the formed product lifecycle. It is becoming increasingly difficult and dangerous to compete in today's market because technology is mobile, government support is unpredictable, and so on. It is hard for innovative companies to win even in the young emerging markets stage, where production costs are critical. It is better to immediately become a technological center, a factory of ideas and technologies, and to form its own international network of manufacturers and developers (Aghion, Bloom, Blundell, Griffith, Howitt, 2005).

The formation of the own innovation system is a tool for the competition of technological formats of companies in the fight for the technological future. The main thing in this competition is to win time, as it is considered to be the main resource in innovative competition. Spreading your own system and displacing a competitor's system means depriving the competitor of its planned future format, its planned chain.

The most important function of forming an extensive and controlled by the firm innovation system is the desire to minimize losses from the "leakage" of the results of technological innovation in favour of competitors and consumers. The fact is that technological innovations, being part of the scientific process, by their very nature have the properties of a public good, i.e., the subject of innovation cannot turn to its own advantage the entire effect of the investments made. Even taking into account all the elements of the existing legal system of protection of property rights to the results of intellectual activity, 
IT companies find themselves in the most vulnerable position in terms of obtaining income on investments in new technologies.

Innovative competition manifests itself in the desire of companies to move to the earliest stages of the product life cycle in order to avoid direct collision within overlapping market niches. As an IT company masters more and more complex stages of the research and production process, it loses interest in those components of business processes that become more accessible to other competitors, especially as the latter become more motivated to catch up with the leader, whose benchmarks become clearer and more accessible. In the field of IT, thanks to the intensive inflow of resources, the development and even improvement of technologies developed by pioneer firms occurs at a very high speed, so leading firms in their desire to rise higher up the technology chain have reached the stage of anticipating and planning the technological development roadmap of the industry. Leaders compete for the right to outline images of the future, for the right to inspire the rest of the IT community (which includes all stakeholders - from software developers and investors to ordinary consumers) with sketches of possible directions of development of the industry (Martins, Terblanche, 2003). This kind of competition involves the active use of non-systemic, psychological methods of influencing competitors and consumers. Firms form a special psychological image of the exclusivity and uniqueness of their key assets, where unique figures of visionary leaders take center stage (Jansen, van Den Bosch, Volberda, 2006). Only these exceptional individuals have the qualities of prophets capable of predicting future technological development and drawing a reliable technological roadmap. Thus, innovative competition becomes irrational, since even the closest competitors are fundamentally unaffordable the business competencies of a charismatic leader.

\section{Problems of administrative and legal regulation of innovative activity of enterprises}

In legal science it is customary to talk about regulating with the help of legal norms a certain range of relations arising between certain subjects. At that, it is difficult to determine the composition of subjects of innovative activity, as well as what relations are innovative. Without an answer to these questions, it is impossible to continue to discuss the applicable method of impact on innovative relations. Thus, there is no possibility to talk about the construction of a new branch of law. The only thing that is possible in this situation is the incorporation (unification) of normative acts containing the term "innovation" according to a certain criterion, for example, legal power (Castro, Clementi, MacDonald, 2009).
In any complex social relations, there are horizontal (civil law) and vertical (administrative law) relations. If to consider innovative relations from the point of view of management, and it is necessary to manage any social process, the leading role belongs to administrative law. If to take the emerging horizontal relations between equal subjects about the use and alienation of innovative objects, the leading role belongs to civil law (Feld, Foigt, 2003).

Attempts to give priority to civil-law relations in the innovation sphere to the detriment of administrative ones will be biased. As the Ukrainian practice shows, the creation and commercialization of new knowledge practically does not happen without the help of the state. Therefore, the state is now pursuing a policy of creating a national innovation system with such a tool as administration, trying to link the commercial calculation of private companies with state coercion.

The Ukrainian state is the largest subject of innovative relations, the main customer of innovative product, which for years has been trying to build relations on contractual, civil law principles for the development and creation of high-tech products, especially in the military sphere on contractual, civillegal principles. There are certain successes in this direction, but the former system of planning and bringing the order to the performer has not yet outlived its usefulness. It is successfully used in foreign practice as well.

The Ukrainian system of contract law has failed in innovation for two main reasons. First, it is difficult to trust the defense of the right enshrined in the contract because of the imperfection of the Ukrainian judicial system, and second, the law of a higher level is subject to constant change. Freedom of contract, stable legislation and a strong independent judiciary in Ukraine during the years of reform have not become a reality for a number of subjective and objective reasons. Since it is predicted that a delay of five to seven years in the creation and development of an effective national innovation system threatens Ukraine with the danger of falling by the wayside in global technological and hence economic development, it seems imperative to return to administration in this area, which, however, is already happening (Blikhar, Vatras, Melnychenko, Podra, Anikina, 2020).

Unfortunately, there is no single normative act uniting the administration in the innovation sphere. Further legal research in the field of administration of innovation activity of enterprises in Ukraine is an urgent need.

Relations on the consolidation of rights to the results of intellectual activity (which were previously sufficiently regulated) turned out to be fully enough regulated, but the movement, dynamics and use of such results were again without proper legal regulation. Correction of such situation will contribute to the 
revival of the turnover of innovative product, improvement of bilateral and multilateral innovative relations arising between business entities in a market economy.

Innovation is intellectual property, to the disposal of which the creator has the exclusive right. The author of innovation (intellectual property) has the right to demand protection of his rights from the claims of third parties. Intellectual property is granted legal protection by the state.

With a literal interpretation of these provisions, it turns out that a number of treaties that existed before are now becoming illegal. This category includes an agreement on assignment of the right to apply for an invention (utility model, industrial design, selection invention), an agreement on assignment of the right to obtain a patent for an invention (utility model, industrial design, selection invention).

Today in Ukraine there is a considerable experience of administrative and legal regulation of innovation activity: since 1991 more than 90 normative legal acts of administrative nature, designed to promote the development of innovative activity of organizations, have been adopted. As a rule, they include:

- establishment of a basic conceptual apparatus and, accordingly, a clear delineation of the scope of application of the law and subsequent subordinate normative legal acts;

- determination of principles, methods and procedure for formation and implementation of the state innovation policy, its priority directions. Establishment of competence of regional bodies of legislative and executive power, as well as specially created bodies (including those acting on a voluntary basis) in the field of innovation activity, determination of forms of interaction with the subjects of scientific and innovation activity;

- establishment of the form, types of support and stimulation of innovation activity, setting the possible amounts and sources of financing. Financing is carried out within the established limits of innovative programs and innovative projects, implemented under the state (republican, regional) orders;

- establishment of the procedure for concluding state agreements (contracts) for the implementation of innovative programs and projects. Freedom of access to information about the priorities of the state innovation policy, about completed research and development works of innovative nature prepared for use in production, about implemented innovative programs and projects (information support of scientific and innovation activity) is guaranteed, except for cases provided for by the legislation on state, official and commercial secrets;

- determination of the form of assistance for training, retraining and advanced training of personnel engaged in innovative activities;
- regulates the creation and activity of innovation and venture capital funds. In some cases, targeted innovation programs are adopted in the form of a law.

Thus, the "innovative" laws can be divided into two main groups:

- "special" laws regulating exclusively innovative activities (Verkhovna Rada of Ukraine, 2002);

- "integrated" laws that combine the regulation of scientific, scientific-technical, and innovative activities.

In turn, each of these groups consists of several subgroups, depending on the object of legal regulation, the emphasis in the regulation of innovation, the predominance of legal norms governing individual issues of innovative activity. Thus, the group of "special" laws includes the following:

- laws on innovation, its development and stimulation;

- laws on state support of innovation activities;

- laws on innovation policy;

- "complex" laws on innovation activity (innovation development) and innovation policy;

- "private" laws, regulating separate questions of innovative activity (for example, innovative activity in the sphere of science and higher education) or its state support (for example, support of subjects of innovative activity, priority innovative projects, innovative activity in the agroindustrial complex).

The most numerous is a subgroup of laws on innovations, their development and stimulation. Laws of this subgroup contain norms about general provisions, about forms of realization of innovation activity, about state innovation policy; about organization, regulation, coordination, financing and state support of innovation activity; final provisions. The laws included in this subgroup are not uniform: along with the presence of common institutions, norms regulating the same aspects of innovative activity, they contain norms that are specific to individual subjects only.

Laws on state support of innovation activities - the next largest subset of laws - Include general provisions; norms on the powers of public authorities in the field of state support of innovation activities and its state regulation, on the forms and measures of state support, including financing; final provisions. Their main difference from the subset of laws on innovation activities is the absence of articles regulating the implementation of innovative activities (forms of implementation of innovative activities) in the framework of the realization of state innovation policy. Another feature of this subset of laws is the presence of articles on the powers of the authorities in the field of state support for innovation, which regulate in detail the social relations connected with state support for the activities of enterprises: issues of goals, principles, directions, and various forms of state support. What these subsets of laws have in common is the existence of articles governing general provisions, financing 
of innovation; and final provisions (Versteeg, Ginsburg, 2017).

Laws on innovation policy is another representative subset of laws, it is characterized by detailed regulation of state innovation policy issues, combining the following elements: goals, principles, objectives, rules, directions, formation, implementation, as well as concepts of innovation policy. Laws of this subgroup contain norms about the basic concepts used in the legislation, the legal basis for the regulation of policy in the field of innovative development; its financing and state support; the powers of public authorities; innovation policy. In some laws you can find the following provisions: on the innovation infrastructure, the responsibility of subjects of innovation activity; on innovation programs; on the councils of innovation policy, inventive and rationalization activity; on the examination of innovation projects.

As for "integrated" laws, they can be divided into:

- laws on innovation and other activities (scientific, research and technological);

- laws on state support of both innovation and other types of activity (scientific, research and technological, investment, production);

- laws on scientific and technical policy of scientific and innovation activities;

- laws on science and research and technology policy, containing chapters on state support for innovation activities.

Compared to the previous group, this one is quite small (14 laws), which makes it difficult to analyze the laws included in it. The exception is a subset of the laws of the subjects on scientific, research and technological, and innovation activities. These laws regulate certain aspects of scientific, research and technology, and innovation activities with different degrees of detail. They define the basic concepts used in the law; designate the legislation on scientific, scientific-technical and innovative activity; distinguish the subjects of scientific, scientific-technical and innovative activity (including "scientific organization", "scientific workers"); there are norms on the organization and regulation of scientific, scientifictechnical and innovative activity, including the management of this activity; on the powers of public authorities, on the formation and implementation of state policy in the field of scientific, scientifictechnical and innovative activity; regulates the issues of financing of scientific, scientific-technical and innovative activity; stimulation and state support of scientific, scientific-technical and innovative activity (Shevchuk, Blikhar, Komarnytska, Tataryn, 2020).

In addition to special "innovation" laws, a number of laws regulating certain aspects in the field of innovation have been adopted. The subject of their regulation, as a rule, are tax benefits to the subjects of innovation activity, budget expenditures to ensure innovation activity, providing local governments with state powers to state support of educational institutions implementing innovative educational programs, operation of technology parks, regulation of innovation activity in certain areas and other issues related to innovations. The analysis shows that this category of laws is diverse and has significant potential in regulating certain aspects of innovative activity.

The legal regulation of a number of aspects connected with realization of innovative activity of the enterprises is carried out by the by-laws. In particular, at the level of by-laws the following is regulated:

- regional target programs for the development of innovative activities;

- measures to develop and stimulate innovation;

- formation of the infrastructure of innovative activity;

- the procedure for creation and accreditation of subjects of the innovation infrastructure;

- procedure for granting subsidies and other forms of property support to subjects of innovation activity (innovation infrastructure) at the expense of the regional budget;

- issues of innovation in education;

- holding competitions of innovative organizations and innovative projects;

- approval of statistical observation forms.

The analysis of the regulatory framework governing the innovative activities of enterprises has revealed a number of problems. The most important of them are: - non-unity in the definition of the fundamental concepts of the innovation sphere;

- absence of unity in determining the powers of executive authorities in the field of innovation;

- inconsistency in the construction of the executive authorities that regulate innovative activity;

- there is no unity in the issue of determining the powers of the executive bodies of state power;

- legal and linguistic ambiguity in the wording of the powers of the executive branch;

- uncertainty of the range of issues on the adoption of normative legal acts regulating relations in the sphere of innovation;

- lack of unity in defining the object of state support;

- non-unity in the interpretation of the concept of "state innovation policy" in the laws;

- ambiguity and vagueness in defining the goals and objectives of the state innovation policy;

- absence of a unified approach to the issue of formation of the participants of the state innovation policy; - different interpretation of the concept of "state support of subjects of innovative activity";

- absence of unity in the definition of the object of state support;

- unclear distinction between the objects of state support and various forms of state support;

- unreasonable limitation of the circle of recipients of state support; 
- excessive administrative barriers in obtaining state support.

Sources of law in the field of innovation are clearly insufficient, and this hinders the creative process in Ukraine. The situation can be corrected by adopting an appropriate unified law.

\section{Conclusion}

Innovative competition is most clearly theorized within the framework of institutional-evolutionary direction of economic theory. The main goal of competition is to maximize control over the institutional and innovative environment of the company, in which value added is created. The field of innovation itself is extremely vulnerable because of leakage of generated benefits, so competitive success here is identified with the minimization of losses from possible technological flows and related methods of extracting added value in favor of competitors. The main vector of the competitive process is the desire of firms to seize control over the initial (upper) floors of the extended life cycle of a product or technology. At the very beginning of the product life cycle there is a stage of institutional and technological design.

Competitive survival in the real mass production of IT products is problematic for any company, since the key routine technological competencies of final assembly are available to many companies. Thus, the barriers to entry in the final assembly market are low and cannot be a source of competitive advantage.

The capture of key competences at the $R \& D$ stage transforms the sources of control over the benefits created in the institutional and innovative environment that exists around the firm, in the direction of strengthening their rent nature. Control over promising patents in order to secure their own technological future and make it difficult for competitors to deploy technological formats is becoming a major source of rental income for IT companies.

However, competition for patents should be viewed more broadly, as one of the key elements of the institutional innovation environment that the firm forms around itself to maximize control over the flows of value created in the process of innovation. The most important element of the institutional innovation environment is a clear vision and implementation of the company's technological roadmap of development and its key technologies responsible for creating attractive products for consumers in the near future. The way in which the technological roadmap is formed defies rational understanding and copying, as it is the realm of creative processes.
The Ukrainian state is the largest subject of innovative relations, the main customer of innovative product, which for years has been trying to build relations on contractual, civil law principles for the development and creation of high-tech products, especially in the military sphere on contractual, civillegal principles. There are certain successes in this direction, but the former system of planning and bringing the order to the performer has not yet outlived its usefulness. It is successfully used in foreign practice as well.

Unfortunately, there is no unified normative act uniting the administration in the innovation sphere. Further legal research in the field of administration of innovation activity of enterprises in Ukraine is an urgent need.

Currently, Ukraine has accumulated considerable experience of administrative and legal regulation of innovation activities: since 1991 it has adopted more than 90 laws and regulations of administrative nature designed to promote innovation activities of organizations.

Analysis of the regulatory framework governing the innovative activities of enterprises has revealed a number of problems. The most important ones are: non-unity in defining the fundamental concepts of the innovation sphere; lack of unity in defining the powers of executive authorities in the innovation sphere; inconsistency in the construction of executive authorities regulating innovation activities; absence of unity in the issue of determining the powers of the executive bodies of state power; legal and linguistic uncertainty in the formulation of the powers of the executive authorities; the uncertainty of the range of issues on the adoption of regulatory legal acts regulating relations in the field of innovation; there is no unity in the definition of the object of state support; lack of unity in the interpretation of the concept of "state innovation policy" in the laws; ambiguity and vagueness in defining the goals and objectives of the state innovation policy; there is no unified approach to the issue of formation by the participants of the state innovation policy; different interpretation of the concept of "state support of subjects of innovative activity"; non- unity regarding the definition of the object of state support; unclear distinction between the objects of state support and various forms of state support; unreasonable limitation of the range of recipients of state support; presence of excessive administrative barriers in obtaining state support. Based on the above, it can be concluded that the administrative and legal regulation in the field of innovation activities of enterprises in a competitive environment is in its formative stage and needs further improvement. 


\section{References:}

Androshhuk, G. O., \& Davymuka, S. A. (2015). Intellectual Capital Migration: Impact on the Economy and Innovative Development. Regional economy, 2, 65-82.

Azoev, G. L. (2010). Competition: analysis, strategy and practice. Marketing in Russia and abroad, 4, 20-28.

Aghion, P., Bloom, N., Blundell, R., Griffith, R., \& Howitt, P. (2005). Competition and innovation: An inverted-u relationship. The Quarterly Journal of Economics, 120(2), 701-728.

Arrow, K. (1962). Economic welfare and the allocation of resources for invention. In C. K. Rowley (Ed.). Readings in industrial economics. London: Palgrave, pp. 219-236.

Baregheh, A., Rowley, J., \& Sambrook, S. (2009). Towards a multidisciplinary definition of innovation. Management Decision, 47(8), 1323-1339.

Blikhar, M. M., Vatras, V., Melnychenko, B., Podra, O., \& Anikina, G. (2020). Providing of innovative development of Ukraine: economic and legal aspects. Financial and Credit Activity: Problems of Theory and Practice, 2(33), 412-423. DOI: https://doi.org/10.18371/fcaptp.v2i33.207098

Blundell, R., Griffith, R., \& Van Reenen, J. (1999). Market share, market value and innovation in a panel of British manufacturing firms. The Review of Economic Studies, 66(3), 529-554.

Caiazza, R. (2015). Explaining innovation in mature industries: Evidences from Italian SMEs. Technology Analysis \& Strategic Management, 27, 975-985.

Castro, R., Clementi, G. L., \& MacDonald, G. (2009). Legal Institutions, Sectoral Heterogeneity, and Economic Development. Review of Economic Studies, 76(2), 529-561.

Dasgupta, P., \& Stiglitz, J. (1980). Industrial structure and the nature of innovative activity. The Economic Journal, 90(358), 266-293.

Feld, L., \& Foigt, S. (2003). Economic growth and judicial independence: Cross country evidence using a new set of indicators. CESifo Working Paper, 906. Munich: CESifo.

Fellner, W. (1951). The influence of market structure on technological progress. The Quarterly Journal of Economics, 65(4), 556-577.

Gerbing, D. W., \& Anderson, J. C. (1988). An updated paradigm for scale development incorporating unidimensionality and its assessment. Journal of Marketing Research, 25(2), 186-192.

Gilbert, R. (2006). Looking for Mr. Schumpeter. Where are We in the Competition-Innovation Debate? Innovation Policy and the Economy, 6, 159-215.

Hasan, I., \& Tucci, C. L. (2010). The innovation-Economic growth nexus: Global evidence. Research Policy, 39(10), 1264-1276.

Jansen, J., van Den Bosch, J., \& Volberda, H. W. (2006). Exploratory innovation, exploitative innovation, and performance: Effects of organizational antecedents and environmental moderators. Management Science, 52(11), 1661-1674.

Martins, E., \& Terblanche, F. (2003). Building organizational culture that stimulates creativity and innovation. European Journal of Innovation Management, 6(1), 64-74.

OECD (1996b). Technology, Productivity and Job Creation. Paris, 84 p.

Shevchuk, V. O., Blikhar, M. M., Komarnytska, I. I., \& Tataryn, N. M. (2020). Rule of law and economic growth. Financial and Credit Activity: Problems of Theory and Practice, 1(32), 278-289. DOI: https://doi.org/10.18371/ fcaptp.v1i32.200522

Tkacheva, O. A., Osadchuk, L. M., Kapustina, I. V., Kobersy, I. S., \& Litvinova, S. F. (2017). Importance of foreign trade in the economic development of Russian regions. International Journal of Applied Business and Economic Research, 15(23), pp. 403-412.

Tsai, W. (2016). Knowledge transfer in intraorganizational networks: Effects of network position and absorptive capacity on business unit innovation and performance. Academy of Management Journal, 44(5), 996-1004.

Verkhovna Rada Ukrainy (2002). The Law of Ukraine "On Innovation Activity" of July 4, 2002 № 40-IV. Bulletin of the Verkhovna Rada of Ukraine, 36, 266.

Versteeg, M., \& Ginsburg, T. (2017). Measuring the Rule of Law: A Comparison of Indicators. Law \& Social Inquiry, 42(1), 100-137. 